\title{
Cryopreservation of Strains and Mutant Genes in Mice
}

\author{
Atsushi YOSHIKI, Kyoko OHNO* and Noboru WAKASUGI \\ Laboratory of animal genetics, School of Agriculture, Nagoya University, \\ Furocho, Chikusa, Nagoya 464, Japan.
}

(Received 9 December 1986/Accepted 19 May 1987)

\begin{abstract}
Three kinds of freezing methods were tested with embryos of DNI strain. The survival rate after thawing was $47.5 \%, 66.7 \%$ and $77.8 \%$ in the 2 -step method, modified slow freezing method and modified 2 -step method, respectively. Then, the modified 2 -step method was applied to the embryos from 7 strains and a pair of interstrain crosses. PMSG treatment at the beginning of diestrus following HCG treatment after $48 \mathrm{hrs}$ resulted in much yield of 8-16-cell embryos in all strains. The average number for each strain was as follows: DNI; 18.9, DDN; 13.0, BS; 20.4, C57BL/6; 12.9, $\mathrm{DBA} / 2 ; 17.5$, CRN ; 19.8, PAN; 13.7 and DNI $\times$ C57BL/6-Ay ; 21.7. Development of frozen-thawed embryos in culture varied among strains. Proportion of embryos that developed to the morula or blastocyst stage was as follows: DNI; $64.6 \%$, DDN; $71.9 \%$, BS; $53.6 \%, \mathrm{C} 57 \mathrm{BL} / 6 ; 57.3 \%, \mathrm{DBA} / 2 ; 65.0 \%, \mathrm{CRN} ; 52.5 \%, \mathrm{PAN} ; 17.4 \%$ and $\mathrm{DNI} \times$ C57BL/6- $\mathrm{A}^{\mathrm{y}} ; 44.1 \%$. These results indicate that the ability of embryos to survive freezing and thawing is influenced by their genetic background. Live young were produced from DNI, DDN, BS and DNI $\times$ C57BL $/ 6-\mathrm{A}^{y}$ embryos after transfer to recipients. Comparative assessment of the developmental ability of frozen-thawed embryos after transfer among strains should be performed in further study.
\end{abstract}

Successful long term frozen-storage of early embryos was first reported in mice in 1972 [13]. Thereafter cryopreservation of embryos was extended to other mammlian species [12], and an idea was proposed to establish embryo banks for a number of purposes, i.e., preservation of genetic stocks, facilitation of their exchange, improvement of farm animals, etc. Some laboratories have started embryo cryopreservation programs for mouse strains and reported comparative assessment of embryo viability after freezing, reestablishment of breeding stocks from frozenstored embryos, and so on $[8,15]$.

The cryopreservation program consists of 4 major procedures, (1) embryo collection from either naturally ovulated or hormone-treated females, (2) freezing and storage in liquid nitrogen, (3) thawing and culture and (4) transfer to pseudopregnant recipients. It seems important to find out an efficient freezing method that would be feasible with simple procedure. Moreover, strain differences have been demonstrated with respects to the performance in the four items mentioned above and feasibility of cryopreservation has been discussed. In addition, F1 embryos from inter-strain crosses is thought to be useful for cryopreservation of mutant genes. Therefore, it seems important to clarify characteristics of embryos from various strains in these respects.

In the present study, we compared the viability of embryos frozen-stored by three different methods. Then we investigated the

Present address: *Institute of Laboratory Animal, Yagi memorial park, Mitakecho, Kanigun, Gifu 505-01, Japan. 
following three items with 7 inbred strains and a pair of interstrain cross, i.e., efficiency of embryo collection after hormone treatment, developmental ability of frozen-thawed embryos in culture and development to young after transfer to recipients.

\section{Materials and Methods}

1. Animals: The strains of mice used in this study were DNI, DDN, BS, C57BL/6, DBA $/ 2$, $\mathrm{CRN}, \mathrm{PAN}$ and $\mathrm{C} 57 \mathrm{BL} / 6-\mathrm{A}^{\mathrm{y}}$. The DNI and DDN strains have been bred from the dd stock which was originally imported from Germany. DNI was bred over 20 generations of brothersister mating at Nippon Institute of Biological Science and introduced to our laboratory in 1978. DDN was introduced from School of Medicine, Nagoya University in 1976 and has been bred 27 generations of sib-matings. BS is a substrain of IXBL and has been maintained by sib-matings for 77 generations. Description of IXBL is given in other publication together with C57BL/6 and DBA/2 [11]. $\mathrm{CRN}$ is a crooked-tail strain. This strain was established by selection for the crooked-tail trait which sporadically appeared in the Japanese laboratory mice belonging to Kasukabe group [5] and has come to 58th generstions of sib-matings. PAN possessing pink-eyed dilution genes is oirginated from F1 hybrids between C57BL/ 6 and a mouse obtained from a fancier and has been maintained for 40 generations of sib-matings. $\mathrm{C} 57 \mathrm{BL} / 6-\mathrm{A}^{\mathrm{y}}$ is the strain in which $A^{\mathrm{y}}$-gene has been introduced into C57BL/ 6 strain by 50 generations of successive backcrosses in our laboratory.

Mice were kept in $17 \times 24 \times 12 \mathrm{~cm}$ wooden cage. Males were housed individually and females were grouped 4-6/cage after weaning. All animals were fed on commercial chicken food (Nihon Nosan Ind., Co., Ltd., Japan) or commercial diet for laboratory mouse (Oriental yeast Co., Ltd., Japan) with water given continuously. Room temperature and light were not controlled except in winter season in which heating was applied to keep the room temperature above $10^{\circ} \mathrm{C}$.

2. Hormone treatment: Embryos were collected from hormone-treated females at $60-150$ days of age in each strain. Before administration of gonadotropins the vaginal smear was observed for $2-5$ days to identify the stage of estrous cycle. On the day both leucocytes and cornified cells were seen in vaginal smear, i.e., at the beginning of diestrus, females were treated with 5-10 IU of pregnant mares' serum gonadotropin (PMSG) and $48 \mathrm{hrs}$ later 5-10 IU of human chorionic gonadotropin (HCG) intraperitonially and then housed with males. Embryos were flushed from oviducts $70-74 \mathrm{hrs}$ after HCG injection with phosphate buffered saline (PB-1) [7]. The embryos were examined with a dissecting microscope and 8 to 16-cell embryos were selected for freezing.

3. Freezing, thawing and embryo transfer: The freezing apparatus is similar to that described by Leibo et al. [1]. Ten to thirty normal embryos were placed in a glass vial ( $3 \mathrm{ml}, 15 \times 50 \mathrm{~mm}$; Pyrex) containing $0.15 \mathrm{ml}$ PB-1. A few minutes later vials were cooled to $0^{\circ} \mathrm{C}$ in an ice bath and then equilibration with the cryoprotective agent, dimethylsulfoxide (DMSO) was carried out, i.e., $0.15 \mathrm{~m} l$ of PB-1 containing $3 \mathrm{M}-\mathrm{DMSO}$ was gradually added to make the final concentration $1.5 \mathrm{M}$. After 15 minutes the samples were transferred to an ethanol bath adjusted at $-7^{\circ} \mathrm{C}$. Three minutes later the samples were seeded by touching the outside wall of a glass vial just above the level of the medium with cooled forceps.

Three different freezing methods, i.e., 2step [16], modified slow [15] and modified 2step freezing methods, were exercised in the present study. In the 2 -step method samples were held at $-20^{\circ} \mathrm{C}$ for 15 minutes (min). In the modified 2-step method embryos were cooled at the rate of $0.6^{\circ} \mathrm{C} / \mathrm{min}$ betweem $-20^{\circ} \mathrm{C}$ and $-30^{\circ} \mathrm{C}$. In the modified slow method cooling was performed at $0.6^{\circ} \mathrm{C} / \mathrm{min}$ betweem $-7^{\circ} \mathrm{C}$ and $-20^{\circ} \mathrm{C}$, and then at $1.0^{\circ} \mathrm{C} / \mathrm{min}$ to $-35^{\circ} \mathrm{C}$. After finishing these procedures the samples were put into liquid nitrogen and stored.

All samples were thawed rapidly by shaking the vials in a hot water bath $\left(40^{\circ} \mathrm{C}\right)$. After thawing dilution of DMSO was performed at room temperature in three steps by adding PB- 1 solution as follows ; firstly $0.5 \mathrm{~m} l$, secondy $0.5 \mathrm{~m} l$ and finally $1.0 \mathrm{~m} l$ with $1 \mathrm{~min}$ 
intervals and then embryos were recovered and washed. They were cultured in microdrops of M2 medium [7] under paraffin oil at $37^{\circ} \mathrm{C}$ in an atmosphere of $5 \% \mathrm{CO}_{2}$ in air. Following 20-24 hrs of culture the number of morphologically normal morulae or blastocysts was recorded.

Embryo transfer was performed by the method described previously [17] to examine the ability of the embryos to develop to normal fetuses. In the present study DNI females were used as recipients.

4. Statistics : Student's t-test was applied for analysis of differences in means. Differences in proportions were analysed by $\mathrm{Chi}$-square test or Fisher's exact probabilty test.

\section{Results}

1. Comparison of freezing methods: Table 1 shows viability of the DNI embryos frozen by three different methods. All samples were stored in liquid nitrogen for 1-67 days. Both groups of DNI embryos frozen-stored for 1 day and 67 days by the modified 2-step method showed the similar survival rate after thawing in culture ( $68.4 \%$ v.s. $69.6 \%)$, indicating that embryo viability was not influenced by the length of storage period up to 67 days. Embryo recovery rate after thawing was about $90 \%$ in all methods. The percentage of morphologically normal embryos after thawing in the 2-step method was significantly lower than those in the others $(p<0.01)$. These results indicate that embryos incurred more damage during freezing and thawing in the 2-step method. Among the three methods no significant difference was seen in the proportion of morulae or blastocysts after culture. However, the difference in overall survival rate between 2step method (47.5\%) and modified 2-step method $(70.8 \%)$ was statistically significant $(\mathrm{p}<0.01)$.

The time required for freezing procedure was $20 \mathrm{~min}$ in both 2 -step and modified 2step methods and 40 min in the modified slow method. Considering both the time required for freezing and survival rate after thawing, we used the modified 2-step method in the following experiments.

2. Embryo collection : Preliminary experiment showed that treatment with 5IU of PMSG and 5IU of HCG resulted in much yield of embryos in DNI, DDN and BS. CRN showed maximum yield when treated with 10IU of each hormone. In C57BL/6, DBA/2 and PAN no apparent trends were observed in the experiments with doses of 5, 7.5 and 10IU. The age of females in these experiments ranged 60-180 days in every strain, and the females aged 160-180 days tended to respond poorly to the hormone treatment. Accordingly, DNI, DDN and BS were treated with 5IU, CRN with 10IU and the others with 7.5IU of each hormone, and all females were used at 60-150 days of age.

Table 2 shows copulation rate, mean nos. of embryos collected and 8 to 16-cell embryos after hormone-treatment. No apparent relation was observed between these items and the age of the females used in each strain. Some

Table 1. Development of 8 to 16 -cell embryos frozen by the different freezing methods on 20-24 hrs of culture after storage (1-67 days) and thawing

\begin{tabular}{|c|c|c|c|c|c|c|}
\hline \multirow{3}{*}{$\frac{\text { Freezing method }}{2 \text {-step }}$} & \multicolumn{3}{|c|}{ No. of 8 to 16 -cell embryos } & \multirow{2}{*}{\multicolumn{3}{|c|}{$\begin{array}{l}\text { No. of embryos } \\
\text { developed to morulae, } \\
\text { blastocysts }\end{array}$}} \\
\hline & \multirow{2}{*}{$\begin{array}{c}\text { frozen } \\
67\end{array}$} & $\begin{array}{l}\text { recovered after } \\
\text { thawing }\end{array}$ & $\begin{array}{c}\text { morphologically } \\
\text { normal }\end{array}$ & & & \\
\hline & & $59(88.1)^{1)}$ & $31 \quad(52.5)^{2) \mathrm{a}}$ & 28 & $(90.3)^{3)}$ & $(47.5)^{4) a}$ \\
\hline Modified slow & 44 & $39 \quad(88.6)$ & $32(82.1)^{\mathrm{b}}$ & 26 & $(81.3)$ & $(66.7)^{a b}$ \\
\hline Modified 2-step & 103 & $89 \quad(86.4)$ & $73(82.0)^{\mathrm{b}}$ & 63 & $(86.3)$ & $(70.8)^{b}$ \\
\hline
\end{tabular}

Numbers in parentheses indicate proportion of the embryos expressed as percentage as follows: 1) Per no. of embryos frozen; 2) Per no. of embryos recovered after thawing; 3) Per no. of embryos morphologically normal; 4) Per no. of embryos recovered. The values with different superscripts are significantly different $(\mathrm{p}<0.01)$. 
Table 2. Embryo collection with PMSG and HCG treatment*

\begin{tabular}{|c|c|c|c|c|c|c|c|}
\hline \multirow{3}{*}{$\begin{array}{l}\text { Strain } \\
\text { DNI }\end{array}$} & \multicolumn{4}{|c|}{ No. of females } & \multirow{3}{*}{$\begin{array}{c}\begin{array}{c}\text { No. of embryos } \\
\text { collected }^{3)}\end{array} \\
30.8 \pm 2.9^{\mathrm{ab}}\end{array}$} & \multirow{2}{*}{\multicolumn{2}{|c|}{$\begin{array}{l}\text { No. of } 8 \text { to } 16 \text {-cell } \\
\text { normal embryos }\end{array}$}} \\
\hline & \multicolumn{2}{|c|}{ used (age) } & \multicolumn{2}{|c|}{ with plug } & & & \\
\hline & 17 & $(60-90)^{1)}$ & 16 & $(94.1)^{2)}$ & & $18.9 \pm 3.2^{\mathrm{ab}}$ & $(61.4)^{4)}$ \\
\hline DDN & 10 & $(60-100)$ & 5 & $(50.0)$ & $21.2 \pm 4.0^{\mathrm{bc}}$ & 13. $0 \pm 4.6^{\mathrm{ab}}$ & $(61.3)$ \\
\hline BS & 14 & $(60-100)$ & 9 & $(64.3)$ & $28.3 \pm 2.4^{\mathrm{ab}}$ & $20.4 \pm 2.7^{\mathrm{ab}}$ & $(72.2)$ \\
\hline C57BL/6 & 13 & $(60-150)$ & 9 & $(69.2)$ & $21.2 \pm 2.1^{\mathrm{c}}$ & $12.9 \pm 1.6^{\mathrm{b}}$ & $(60.7)$ \\
\hline $\mathrm{DBA} / 2$ & 16 & $(60-100)$ & 11 & $(68.8)$ & $24.3 \pm 3.8^{\mathrm{bc}}$ & $17.5 \pm 2.5^{\mathrm{ab}}$ & $(71.9)$ \\
\hline CRN & 16 & $(60-150)$ & 14 & $(87.5)$ & $29.9 \pm 2.9^{\mathrm{ab}}$ & $19.8 \pm 3.0^{\mathrm{ab}}$ & $(66.3)$ \\
\hline PAN & 14 & $(60-150)$ & 9 & $(64.3)$ & $20.2 \pm 2.7^{\mathrm{c}}$ & 13. $7 \pm 1.9^{b}$ & $(67.6)$ \\
\hline $\mathrm{DNI} \times \mathrm{C} 57 \mathrm{BL} / \mathrm{A}^{\mathrm{y}}$ & 8 & $(60-90)$ & 6 & $(75.0)$ & $36.2 \pm 5.8^{\mathrm{a}}$ & $21.7 \pm 2.6^{\mathrm{a}}$ & $(59.9)$ \\
\hline
\end{tabular}

* For doses of hormones, see text. 1) The age of females used (days). 2) Proportion of females with plugs to the females paired. 3) Mean \pm SEM. 4) Proportion of normal embryos to the eggs collected. Values with different superscripts are significantly different from each other $(p<0.05)$.

a

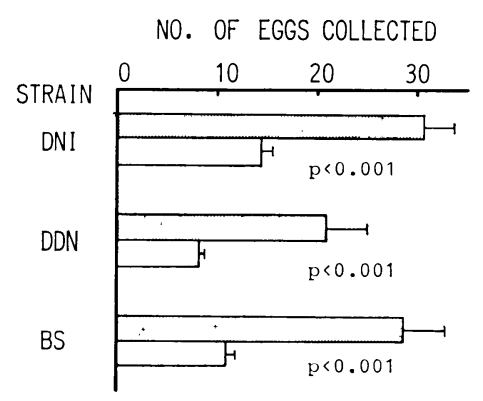

b

NO. OF 8 16-CELL EMBRYOS

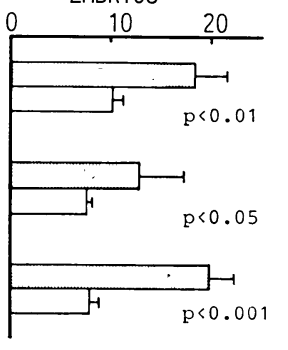

C

$\%$ OF ABNORMAL EMBRYOS

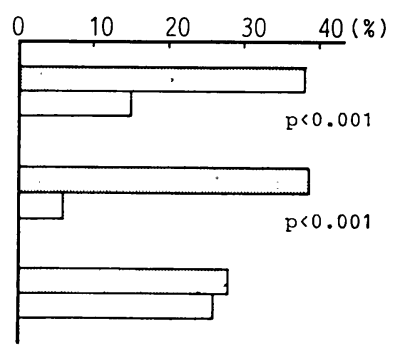

Hormone-treated group

Natural mating group

(a): Mean ( \pm SEM) number of eggs collected, (b) : mean ( \pm SEM) number of 8-16cell embryos, and (c): percentage (per no. of eggs collected) of abnormal embryos. Statistically significant difference is shown by $\mathrm{p}$ value ( $\mathrm{a}, \mathrm{b} ; \mathrm{t}$-test, $\mathrm{c}: \chi^{2}$-test).

Fig. 1. Effects of PMSG and HCG-treatment on embryo collection in three inbred strains.

differences in copulation rate were noted among strains, ranging from 50.0 to $94.1 \%$. The DNI females mated to $\mathrm{C} 57 \mathrm{BL} / 6-\mathrm{A}^{\mathrm{y}}$ males produced significantly greater no. of total embryos than did the DDN, C57BL/6, DBA/2 and PAN females $(p<0.05)$. The DNI, BS and CRN strains also produced significantly more embryos than the $\mathrm{C} 57 \mathrm{BL} / 6$ and PAN strains $(\mathrm{p}<0.05)$. Numbers of 8 to $16-$ cell embryos in C57BL/ 6 and PAN strains were significantly less than $\mathrm{DNI} \times \mathrm{C} 57 \mathrm{BL} / 6-\mathrm{A}^{\mathrm{y}}$ cross. The percentage of normal embryos ranged from 60 to $70 \%$, and no significant difference was seen among strains. Most of the abnormal embryos were fragmented or delayed ones (2 to 4-cell). Some unfertilized ova were also observed.

To assess the effect of hormones on egg yield we compared hormone-treated groups with naturally mated ones in three strains, DNI, DDN and BS (Fig. 1). Both total no. of eggs and 8 to 16-cell normal embryos were significantly increased by hormone-treatment $(\mathrm{p}<0.05)$. The treatment also increased the proportion of abnormal embryos in DNI and DDN $(\mathrm{p}<0.001)$.

3. Viabilty after freezing, thawing and trans- 
Table 3. In vitro development of frozen-thawed embryos ${ }^{1}$

\begin{tabular}{|c|c|c|c|c|c|}
\hline \multirow{2}{*}{ Strain } & \multirow{2}{*}{$\begin{array}{l}\text { Storage } \\
\text { period } \\
\text { (days) }\end{array}$} & \multirow{2}{*}{$\begin{array}{l}\text { No. of } \\
\text { embryos } \\
\text { frozen }\end{array}$} & \multicolumn{2}{|c|}{ No. of embryos } & \multirow{2}{*}{$\begin{array}{l}\text { No. developed to } \\
\text { morulae/blastocysts } \\
\qquad(\%)\end{array}$} \\
\hline & & & $\begin{array}{l}\text { recovered } \\
(\%)\end{array}$ & $\begin{array}{l}\text { morphologically } \\
\text { normal }(\%)\end{array}$ & \\
\hline DNI & $(2-37)$ & 204 & $175(85.8)^{\mathrm{ab} 2)}$ & $133(76.0)^{\mathrm{b} 3)}$ & $113(85.0)^{\left.\mathrm{a}^{4}\right)}(64.6)^{\mathrm{ab} 5)}$ \\
\hline DDN & $(1-21)$ & 75 & $64(85.3)^{a b}$ & $57(89.1)^{a}$ & $46(80.7)^{\mathrm{ab}}(71.9)^{\mathrm{a}}$ \\
\hline BS & $(1-21)$ & 107 & $97(90.6)^{a b}$ & $73(75.3)^{\mathrm{b}}$ & $52(71.2)^{\mathrm{bc}}(53.6)^{\mathrm{bc}}$ \\
\hline C57BL/6 & $(13-32)$ & 100 & $82(82.0)^{\mathrm{b}}$ & $54(65.9)^{\mathrm{c}}$ & $47(87.0)^{\mathrm{a}} \quad(57.3)^{\mathrm{abc}}$ \\
\hline $\mathrm{DBA} / 2$ & $(3-49)$ & 87 & $80(92.0)^{\mathrm{a}}$ & $64(73.6)^{\mathrm{b}}$ & $52(81.3)^{\mathrm{ab}}(65.0)^{\mathrm{ab}}$ \\
\hline $\mathrm{CRN}$ & $(1-50)$ & 113 & $101(89.4)^{\mathrm{ab}}$ & $68(67.3)^{\mathrm{bc}}$ & $53(77.9)^{\mathrm{ab}}(52.5)^{\mathrm{bc}}$ \\
\hline PAN & $(20-26)$ & 53 & $46(86.8)^{a b}$ & $17(37.0)^{\mathrm{d}}$ & $8(47.1)^{\mathrm{c}} \quad(17.4)^{\mathrm{d}}$ \\
\hline $\mathrm{DNI} \times \mathrm{C} 57 \mathrm{BL} / 6-\mathrm{A}^{\mathrm{y}}$ & $(25-40)$ & 102 & $93(91.2)^{a b}$ & $56(60.2)^{c}$ & $41(73.2)^{\mathrm{ab}}(44.1)^{\mathrm{c}}$ \\
\hline
\end{tabular}

1) All embryos were frozen by the modified 2-step method, stored for 1-50 days and cultured for 24 hrs after thawing. Numbers in parentheses indicate proportion of the embryos expressed as percentage as follows; 2) Per no. of embryos frozen. 3) Per no. of embryos recovered. 4) Per no. of embryos morphologically normal. 5) Per no. of embryos recovered. Values with different superscripts are significantly different from each other $(\mathrm{p}<0.05)$.

fer: Table 3 shows in vitro development of frozen-thawed embryos. Recovery rate ranged from 82.0 to $92.0 \%$ and no significant difference was seen among strains except between C57BL/6 and DBA/2 $(\mathrm{p}<0.05)$. The embryos that could not be recovered were thought to be completely destroyed during the procedure or lost at pipetting. The difference in storage period did not seem to change embryo viability in each strain. And this point was examined statistically in DNI and DBA/ 2 embryos (DNI ; 2-7 day-storage; $61.2 \%$ v.s. 37 day-storage; $63.3 \%, \mathrm{DBA} / 2 ; 3$ day-storage ; $68.6 \%$ v.s. 42 day-storage; $66.7 \%)$. Strain differences were observed in the proportion of morphologically normal embryos at recovery and developing ability in culture. Proportion of morphologically normal embryos in DDN was significantly higher than that in other strains $(\mathrm{p}<$ 0.05). In contrast, the proportion in PAN was significantly lower as compared with other strains $(p<0.05)$. The embryos classified as abnormal had swollen or degenerated blastomeres accompanied by cytoplasmic darkening or damaged zona pellucida. Significant strain differences were found in the proportion of embryos that developed to morulae or blastocysts after 24 hours' culture $(\mathrm{p}<0.05)$. The DNI and C57BL/6 embryos showed higher survival rate. The PAN showed significantly lower survival rate than other strains $(\mathrm{p}<$
0.05). With regard to the overall survival rate $\mathrm{BS}, \mathrm{CRN}, \mathrm{DNI} \times \mathrm{C} 57 \mathrm{BL} / 6-\mathrm{A}^{\mathrm{y}}$ and $\mathrm{PAN}$ embryos were inferior to other 3 strains and PAN strain showed the lowest percentage.

Developmental ability of frozen-thawed embryos was compared with that of unfrozen fresh embryos in the four strains, DNI, DDN, BS and C57BL/6 (Table 4). Significant difference was seen in each strain $(p<0.01)$.

Table 4. Influence of freezing and thawing on embryo development in vitro ${ }^{1)}$

\begin{tabular}{llrrl}
\hline \multirow{2}{*}{ Strain } & & \multicolumn{3}{c}{ No. of embryos } \\
\cline { 3 - 5 } & & cultured & $\begin{array}{r}\text { developed to morulae } \\
\text { or blastocysts (\%) }\end{array}$ \\
\hline \multirow{2}{*}{ DNI } & Frozen & 133 & 113 & $(85.0)^{\mathrm{a} 2)}$ \\
& Fresh & 99 & 98 & $(99.0)$ \\
\hline \multirow{2}{*}{ DDN } & Frozen & 57 & 46 & $(80.7)$ \\
& Fresh & 92 & 86 & $(93.5)$ \\
\hline \multirow{2}{*}{ BS } & Frozen & 61 & 44 & $(72.1)^{\mathrm{c}}$ \\
& Fresh & 53 & 51 & $(96.2)$ \\
\hline \multirow{2}{*}{ C57BL/6 } & Frozen & 54 & 47 & $(87.0)^{\mathrm{c}}$ \\
& Fresh & 76 & 75 & $(98.7)$
\end{tabular}

1) Embryos were cultured from 8-16-cell stage in medium $\mathrm{M} 2$ in an atomospher of $5 \% \mathrm{CO}_{2}$ in air at $37^{\circ} \mathrm{C}$ for 24 hours. 2) Percentage to the number of embryos cultured. Superscripts indicate significant difference from the control $(\mathrm{a} ; \mathrm{p}<0.001, \mathrm{~b} ; \mathrm{p}<0.02$, c; $\mathrm{p}<0.01$ ). 
These results suggested that the significant damage had occurred during freezing and thawing process that was not detectable under low-magnification microscope $(\times 80)$.

The frozen-thawed embryos were transferred to the pseudopregnant DNI recipients. The PAN embryos were too few to be used for transfer. Some offsprings were produced

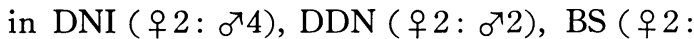
$\left.\sigma^{\top} 2\right)$ and $\mathrm{DNI} \times \mathrm{C} 57 \mathrm{BL} / 6-\mathrm{A}^{\mathrm{y}}\left(\right.$ 우 $\left.2: \sigma^{\top} 4\right)$. In DBA $/ 2$ and CRN a few neonates were born but were killed by the mothers. No live young were produced from C57BL/6 embryos. From F1 (DNI $\times$ C57BL $\left./ 6-\mathrm{A}^{\mathrm{y}}\right)$ embryos 5 yellow coated and 1 black coated mice were produced and they showed normal fertility, indicating that $A^{\mathrm{y}}$-gene was successfully preserved.

\section{Discussion}

Advantages of frozen storage of strains in the form of embryos have been mentioned by others $[2,4,14]$. In some laboratories an automatic freezing apparatus is used for efficient embryo freezing. But Pye and his colleagues suggest the difficulty in justifying the purchase of expensive freezer only for embryo freezing [6]. The present study has shown that several mouse strains are successfully frozen-stored by simple equipment.

High copulation rate and superovulation could be induced by PMSG treatment at the beginning of diestrus following HCG treatment after $48 \mathrm{hrs}$ (Table 2). High ovulation rate was confirmed in DNI, DDN and BS as compared with natural matings (Fig. 1a). These results indicate the advantage of this method in obtaining embryos from valuable strains that show poor reproductive performance. Strain differences in egg yield after hormonetreatment were observed. Many workers also have reported the genetic variation in egg yield after gonadotropin treatment $[8,15]$. Spearow and Bradford have suggested genetic differences for the diversity in the numbers of developing follicles and the rate of $\mathrm{LH}$ receptor synthesis $[9,10]$. A possibility has been suggested that some portion of the abnormal embryos might be ovulated in response to PMSG treatment [8]. It is also suggested that the hormone-treatment might result in abnormal oogenesis and chromosomal abnormalities [3]. In the present study the proportion of abnormal embryos increased by the hormone treatment in DNI and DDN strains, whereas, no significant increase was seen in BS strain. These results indicate that each strain has its intrinsic responsiveness to exogeneous gonadotropins, which is thought to influence the efficiency of embryo collection.

We found the deleterious effect of freezing and thawing procedure on embryo development in culture after thawing (Table 4). In all 4 strains examined, normal appearing frozenthawed embryos developed less well than fresh ones. Cytoplasmic ice formation or osmotic change during the procedure may have affected substantially cell function of the arrested and degenerated embryos. It would be necessary to establish the freezing method that gives less damage to embryos and yields better viability.

It has been shown that length of storage period does not greatly influence embryo viability [15]. The same was observed in our experiment in which three kinds of freezing methods were compared. Therefore, the differences in survival rate after thawing among strains (Table 3) do not seem to be due to the difference in length of storage period.

Some investigators have reported that postthaw viability of embryos is influenced by their genotypes $[8,15]$. In our results also, variations among strains were observed. F1 $\left(\mathrm{DNI} \times \mathrm{C} 57 \mathrm{BL} / 6-\mathrm{A}^{\mathrm{y}}\right)$ embryos unexpectedly showed lower survival rate than those of DNI and C57BL/6 strains. Schmidt et al. observed an influence of the male genotype on the ability of embryos to survive cryopreservation and suggested complementation of various genes contributing to the integrity of the embryos and their survival rate [8]. This view may explain the low survival rate of the F1 embryos to some degree. The effect of $A^{\mathrm{y}}$-gene might also be involved. However, it remains uncertain whether $A^{\mathrm{y}}$-gene exerted deleterious effect on the survival rate or not, since the embryo transfer resulted in an excess production of yellow coated mice over black coated ones. PAN strain possessing $p$ (pink 
eye dilution) gene showed the lowest survival rate and embryo transfer was not performed. For preservation of $p$-gene, it may be useful to use F1 embryos of PAN and other strains. The effect of $A^{y_{-}}$and $p$-genes on the ability of embryos to survive cryopreservation should be revealed to assess the feasibility of mutant gene preservation.

In the present study, DNI, DDN and BS strains and $A^{\mathrm{y}}$-gene were successfully preserved by frozen-storage of embryos. Since data of embryo transfer are limited, further transfer experiments should be performed to assess the viability of the frozen-thawed embryos after transfer for each strain.

\section{Acknowledgement}

The authors wish to thank Prof. T. Tomita, Dr. T. Namikawa and Dr. Y. Kawamoto, Laboratory of Animal Genetics, School of Agriculture, Nagoya University, Japan, for their valuable suggestions and Mrs. T. Hayakawa and Miss S. Narita for taking care of animals. This study was performed through Special Coordination Funds of the Science and Technology Agency of the Japanease Govern. ment.

\section{References}

[1] Leibo, S.P., and Mazur, P. (1978). Methods for the preservation of mammalian embryos by freezing. In Methods in Mammalian Reproduction, pp. 179-201, Daniel, J. (edit.), Academic Press Inc., New York.

[2] Leibo, S. P. (1981). Introduction to embryo freezing. In Frozen Storage of Laboratory Animals, pp. 1-19, Zeilmaker, G.H. (edit.), Gustav Fischer Verlag, Stuttgart, New York.

[3] Luckett, D. C., and Mukherjee, A. B. (1986). Embryonic characteristics in superovulated mouse strains. J. Hered., 77, 39-42.

[4] Mobraaten, L.E. (1981). The Jackson Laboratory
Genetics Stocks Resource Repository. In Frozen Storage of Laboratory Animals, pp. 165-177, Zeilmaker, G.H. (edit.), Gustav Fischer Verlage, Stuttgart, New York.

[ 5 ] Nozawa, K., and Kondo, K. (1971). Genetical study on the Japanese crooked-tail in the mouse. Japan J. Genetics, 46, 109-123.

[ 6 ] Pye, J., Holmes, M.C., and Crawford, M. (1981). A simple piece of equipment for controlled cooling and freezing of mouse embryos. In Frozen Storage of Laboratory Animals, pp. 61-66, Zeilmaker, G. H. (edit.), Gustav Fischer Verlag, Stuttgart, New York.

[7] Quinn, P., Barros, C., and Whittingham, D. G. (1982). Preservation of hamster oocytes to assay the fertilizing capacity of human spermatozoa. J. Reprod. Fert., 66, 161-168.

[8] Schmidt, P.M., Hansen, C. T., and Wildt, D. E. (1985). Viability of frozen-thawed mouse embryos is affected by genotype. Biol. Reprod., 32, 507514.

[9] Spearow, L. J. (1981). Genetics of gonadotropin induced ovulation rate and $\mathrm{LH}$ receptor induction. Biol. Reprod., 24 (supple. 1): 110A, Abstr \$176.

[10] Spearow, J.L. (1983). Genetic variation in spontaneous ovulation rate and $\mathrm{LH}$ receptor induction in mice. J. Reprod. Fertil., 69, 529-537.

[11] Staats, J. (1976). Standardized nomenclature for inbred strains of mice: sixth listing. Cancer Res., 36, 4333-4377.

[12] Utsumi, K. (1981). In Early Development of Mammals, pp. 229-256, Tokyo Rikogakusha.

[13] Whittingham, D.G., Leibo, S.P., and Mazur, P. (1972). Survival of mouse embryos frozen to $-196^{\circ} \mathrm{C}$ and $-269^{\circ} \mathrm{C}$. Science, 178, 411-414.

[14] Whittingham, D.G. (1974). Embryo banks in the future of developmental genetics. Genetics, 78, 395-402.

[15] Whittingham, D.G., Lyon, M.F., and Glenister, P.H. (1977). Re-establishment of breeding stocks of mutant and inbred strains of mice from embryos stored at $-196^{\circ} \mathrm{C}$ for prolonged periods. Genet. Res., 30, 287-299.

[16] Wood, M.J., and Farrant, J. (1980). Preservation of mouse embryos by two-step freezing. Cryobiology, 17, 178-180.

[17] Yokoyama, M., Wakasugi, N., and Nomura, T. (1981). An attempt to store inbred mouse strains. In Frozen Storage of Laboratory Animals, pp. 113-117, Zeilmaker, G.H. (edit.), Gustav Fischer Verlag, Stuttgart, New York. 
凍結脹によるマウスの系統及び突然変異遺伝子保存

吉木淳·大野京子*·若杉 昇

名古层大学農学部家畜育種学教室

凍結胚による系統保存あるいは遗伝子保存の可能性に ついて調べることを目的として, 凍結方法の検討を行 い, 7 系統の マウス (DNI, DDN， BS， C57BL/6, $\mathrm{DBA} / 2, \mathrm{CRN}, \mathrm{PAN})$ と 1 組の系統間交配 (DNI $\times$ C57BL/6-Ay) について胚の採取方法および凍結保存後 の胚の生存性を調べた。DNI 肧を用いて検討したとこ 万修正 2-step 法が肧の生存率 (77.8\%) あ比較的高く 短時間で行える簡便な方法であることが示され，他系統 の胚にもこの方法を応用した。凍結融解後の胚の発生率
には系統差が見られ，PAN では最も低く(17.4\%)， DDN では最も高かった (71.9\%)。凍結融解後, 桑実 胚や胚盤胞に発生した卯を仮親に移植した結果, DNI, $\mathrm{DDN}, \mathrm{BS}$ 肧より産子が得られ，また $\mathrm{F}_{1}$ 胚 (DNI $\times$ C57BL/6-Ay) より 5 匹の黄色マウスが得られた。以上 の結果, 簡便な修正 2-step 法により数系統のマウスの 凍結保存および遺伝子保存が可能である事が示された。 今後は, 凍結融解胚の移植後の生存率について各系統で 検討することが必要であろう。 